\title{
Static and dynamic measurements on glass panes - experimental analysis
}

\author{
Ján Brodniansky ${ }^{1, *}$, Luboš Balcierák ${ }^{2}$, Martin Magura ${ }^{1}$ and Ján Brodniansky prof. ${ }^{1}$ \\ ${ }^{1}$ Slovak University of Technology in Bratislava, Faculty of Civil Engineering, Department of Steel \\ and Timber Structures, Bratislava, Slovakia \\ ${ }^{2}$ INGSTEEL, spol. s r.o., Bratislava, Slovakia
}

\begin{abstract}
The paper presents testing of glass panels, static test and dynamic test by hard body impact. Pendulum test is presented. Test procedure is described as well as tested samples and their material characteristics. The glass type of tested samples were laminated and float glass, as well as the age of the glass samples were different.
\end{abstract}

\section{Introduction}

Glass is a fragile elastic material with different strength characteristics in compression and tension. There are many glass products manufactured to be used in construction industry. In civil engineering mainly plane (plate) products. The essential requirement for the glass plate is its sufficient resistance. Various previous research were done in this area. Experimental mechanical analysis of traditional in-service glass windows subjected to dynamic tests and hard body impact were examined in [1,2]. Experimental Analysis of Impact and Blast Resistance were studied by Kruszka e Rekucki in [3,4]. Dynamic and static tests of glass plate using pendulum test with steel ball were conducted by Papan and described in $[5,6]$. Zvakova analysed test procedure of the window systems in [7]. The resistance of windows systems were studied in $[8,9]$.

Presented paper describes one part of the experimental research made by former $\mathrm{PhD}$. student L. Balcierák with help of colleagues from Department of Steel and Timber Structures, from Faculty of Civil Engineering, Slovak University of Technology in Bratislava. Some previous results were published in $[10,11]$. Main aim of this research was to study impact loads on glass panes (panels) and possibilities of different types of experimental measurements which were withstanding during the presented research.

Glass plate products can be differentiated according to manufacturing process as: float glass; strengthened glass (tempered glass, chemically strengthened glass); layered (laminated) glass. Glass properties are caused mainly due to its silica dioxide contents and different strengths in tension and compression are caused by microfractures and microscopical defects reducing tensile strength. Research was focused on float glass panes and laminated glass panes. Typical material characteristics of flat glass are $E=70 \mathrm{GPa}$ (Young's modulus of elasticity); tensile strength $20-150 \mathrm{MPa}$.

\footnotetext{
* Corresponding author: jan brodniansky@stuba.sk
} 
Experimentally measured material characteristics of flat glass panes were $E=70.21 \mathrm{GPa}$ and tensile strength of $51.13 \mathrm{MPa}$ (deformation of glass pane $25 \mathrm{~mm}$ ). These values were measured in accordance with standard EN 1288-3 [14] (four point bending test). Totally there were used 4 samples of glass panes with size $1100 \mathrm{~mm}$ x $360 \mathrm{~mm}$ x $6 \mathrm{~mm}$.

\section{Pendulum test of glass panes}

Standard DIN EN 12600 [12] describes test and classification procedures of flat glass elements and its behaviour under the impact load and after damaging glass pane. Test sample is graded according to the impact energy which is directly proportional to the height difference of the impact body (difference between equilibrium position and position with prescribed amplitude). Energy generated by impact of the impact body represents impact of moving person at different speeds. Main purpose of the standard [12] is to enhance safety in regards of possible cuts and stab wounds caused by sharp glass fragments. It does not specify requirements for the design of the glass element. It specifies that the sample is either a compact (without any visible cracks) or it breaks in-to fragments (which can be dangerous for people standing near flat glass panels of hitting them). There are specified glass classifications according to height of the fall of the impact body: 3-fall height of 190mm; 2fall height of $450 \mathrm{~mm} ; 1$-fall height of $1200 \mathrm{~mm}$. Figure 1 shows the whole test assembly with its components.

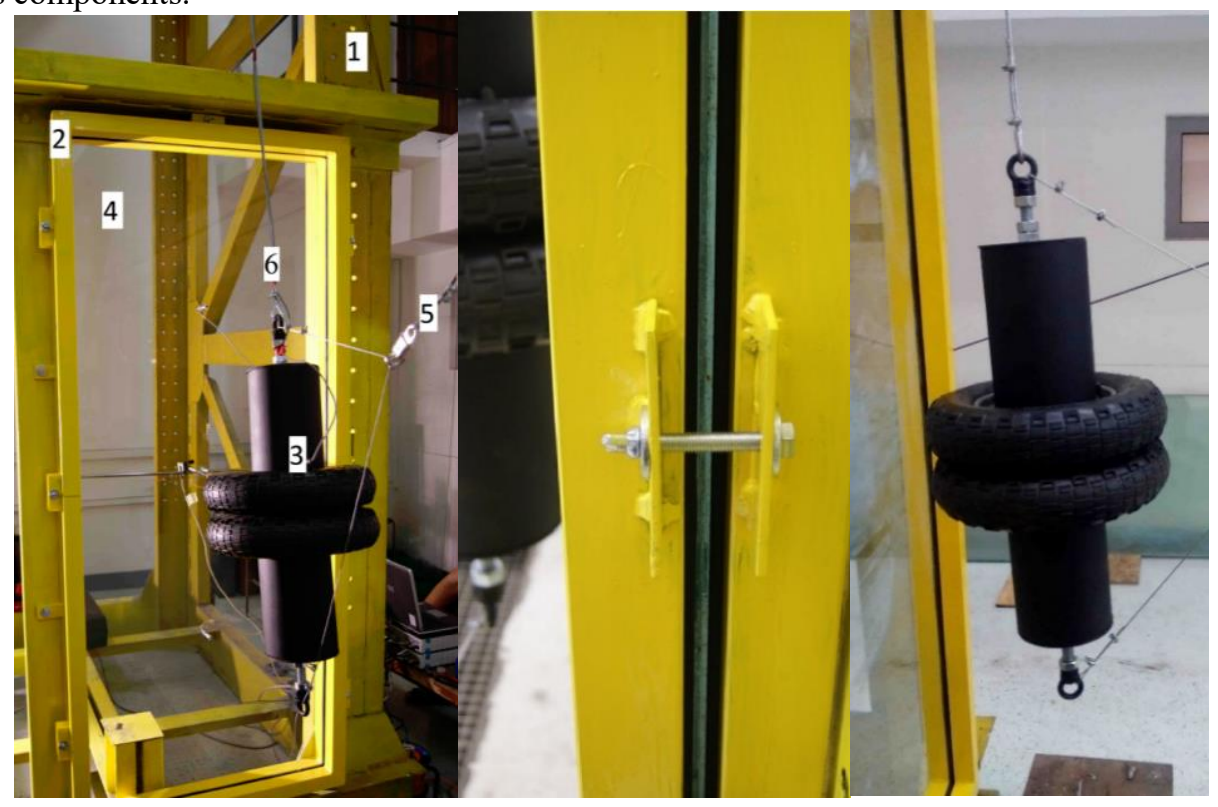

Fig. 1. Test assembly; main frame (1); chucking frame (2); impact body (3); glass sample (4); intermediate hanger (5); impact body hanger (6).

Minimum of four test samples of the same thickness were recommended. Size of prepared samples was $840 \mathrm{~mm}$ x $2010 \mathrm{~mm}$. For pendulum tests were used 20 samples shown in table 1. 
Table 1. Test samples for pendulum test.

\begin{tabular}{|c|c|c|c|}
\hline Sample & $\begin{array}{c}\mathbf{N}^{\circ} \text { of } \\
\text { samp } \\
\text { les }\end{array}$ & Thickness & Description \\
\hline Laminated glass & 4 & $3 \mathrm{~mm}+0.38 \mathrm{~mm}+3 \mathrm{~mm}$ & 15 years old samples \\
\hline Laminated glass & 4 & $3 \mathrm{~mm}+0.38 \mathrm{~mm}+3 \mathrm{~mm}$ & New samples \\
\hline Float glass & 4 & $3 \mathrm{~mm}+3 \mathrm{~mm}$ & New samples \\
\hline Float glass & 4 & $6 \mathrm{~mm}$ & New samples \\
\hline Float glass & 4 & $4 \mathrm{~mm}$ & New samples \\
\hline
\end{tabular}

Besides of standard [12] the same impact body is used in glass tests according to standard DIN 18008-4 [13]. Standard [13] is primarily used for vertical glass elements as are glass fillings for windows, glass fillings for railings etc. There are set three glazing categories according to height of the fall of the impact body: A-fall height of $900 \mathrm{~mm}$; B-fall height of $700 \mathrm{~mm}$; C-fall height of $450 \mathrm{~mm}$.

\section{Experimental measurements conducted on glass pane}

Experimental testing was conducted accordance with the standard [12]. The standard require three height levels. Due to the possibility of total glass destruction in first impact, there were chosen these height levels: $50 \mathrm{~mm} ; 100 \mathrm{~mm} ; 150 \mathrm{~mm} ; 190 \mathrm{~mm} ; 250 \mathrm{~mm} ; 450 \mathrm{~mm}$ and $1200 \mathrm{~mm}$. Test starts by the lowest level and continuous to the higher level. Only one impact for each level is allowed (impact body must be stabilized immediately after first contact with the glass sample no secondary impact is allowed).
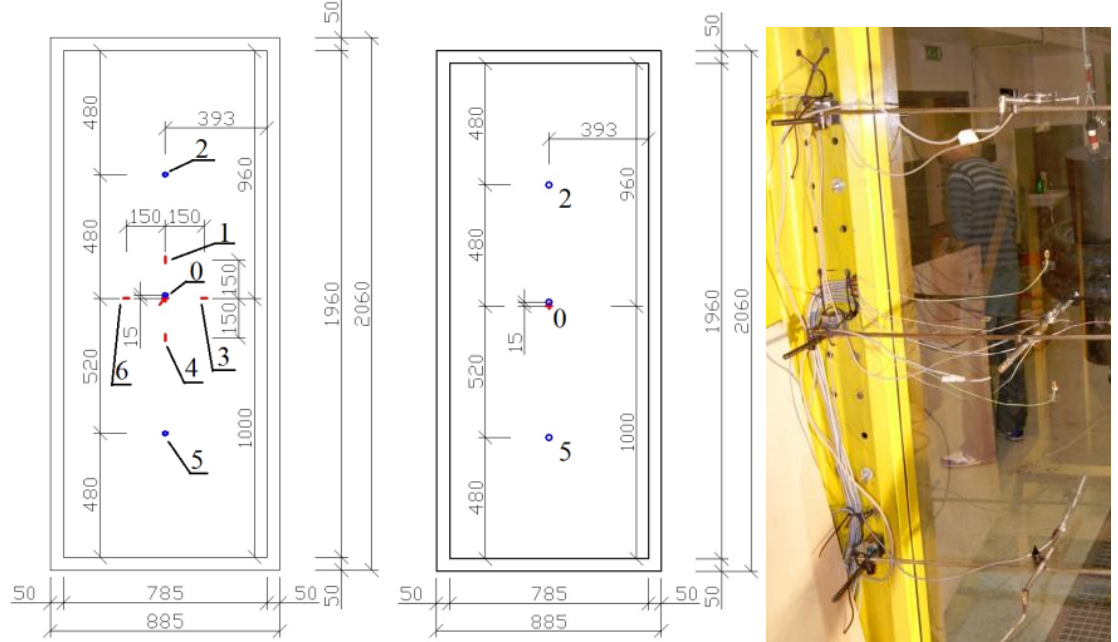

Fig. 2. Measuring configuration positions: 0, 1, 3, 4, 6-strain gauges; 0, 2, 5-measuring needles (deform meters); $0,2,5$ - accelerometers

During experiment were measured strains, deformations, and accelerations of glass samples in positions described in fig. 3. Table 2 shows values measured during experiment on different types of glass panes. 
Table 2. Measured stresses and deformation in point 0 .

\begin{tabular}{|c|c|c|c|c|c|c|c|c|c|c|c|c|}
\hline \multirow{3}{*}{$\begin{array}{c}\text { Fall } \\
\text { height } \\
{[\mathrm{mm}]}\end{array}$} & \multicolumn{12}{|c|}{$\mathbf{V}$-vertical stresses [MPa] H-horizontal stresses [MPa] D-deformation [mm] } \\
\hline & \multicolumn{3}{|c|}{ Float glass $-6 \mathrm{~mm}$} & \multicolumn{3}{|c|}{$\begin{array}{c}\text { Laminated } \\
3+0,38+3 \mathrm{~mm}\end{array}$} & \multicolumn{3}{|c|}{$\begin{array}{c}\text { Laminated old } \\
3+0,38+3 \mathrm{~mm}\end{array}$} & \multicolumn{3}{|c|}{$\begin{array}{l}\text { Float glass not glued } \\
3+3 \mathrm{~mm}\end{array}$} \\
\hline & $\mathbf{V}$ & $\mathbf{H}$ & $\mathbf{D}$ & $\mathbf{V}$ & $\mathbf{H}$ & D & $\mathbf{V}$ & $\mathbf{H}$ & D & $\mathbf{V}$ & $\mathbf{H}$ & $\mathbf{D}$ \\
\hline 50 & 31.64 & 46.96 & 9.24 & 32.44 & 47.37 & 9.05 & 32.46 & 47.66 & 9.11 & 33.02 & 53.42 & 16.00 \\
\hline 100 & 40.66 & 61.53 & 12.35 & 41.22 & 61.64 & 11.93 & 43.38 & 64.61 & 12.21 & 47.20 & 68.72 & 21.26 \\
\hline 150 & 45.99 & 69.95 & 15.19 & 47.69 & 69.92 & 14.73 & - & - & 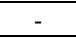 & 52.24 & 70.58 & 25.32 \\
\hline 190 & 49.56 & 75.42 & 16.96 & 50.95 & 74.49 & 15.84 & 49.01 & 76.37 & 17.27 & - & - & - \\
\hline 250 & 52.28 & 77.45 & $\begin{array}{l}18.37 \\
\end{array}$ & 54.91 & 77.08 & 17.84 & - & - & - & - & - & - \\
\hline 450 & 63.40 & $\begin{array}{l}88.05 \\
\end{array}$ & 22.49 & 66.61 & 86.56 & 21.65 & - & - & - & - & - & - \\
\hline
\end{tabular}

Measured accelerations were analysed to calculate frequencies and damping coefficient of the whole test assembly shown in Table 3 .

Table 3. Frequencies and dumping coefficient of test assembly.

\begin{tabular}{|c|c|c|c|c|}
\hline \multirow{2}{*}{ Glass pane } & \multirow{2}{*}{$\begin{array}{c}\text { Frequency } \\
{[\mathrm{Hz}]}\end{array}$} & \multicolumn{3}{|c|}{ dumping coefficient (logarithmic decrement of dumping) } \\
\cline { 3 - 5 } & 13.04 & Fall height $100 \mathrm{~mm}$ & Fall height $250 \mathrm{~mm}$ & Fall height 450mm \\
\hline $3 \mathrm{~mm}$ & 17.14 & 0.16 & - & - \\
\hline $4 \mathrm{~mm}$ & 26.09 & 0.14 & 0.10 & 0.07 \\
\hline $6 \mathrm{~mm}$ & 11.11 & 0.10 & 0.12 & 0.15 \\
\hline 3+3mm not glued & 26.09 & 0.42 & 0.81 & - \\
\hline New 3+0,38+3mm & 26.08 & 0.29 & 0.27 & 0.25 \\
\hline Old 3+0,38+3mm & \multicolumn{3}{|c}{} \\
\hline
\end{tabular}

Besides impact tests there were conducted static loading test (Fig.3) on $4 \mathrm{~mm}$ float glass panes and values compared with impact measurements. Comparison of measured values are in Table 4.
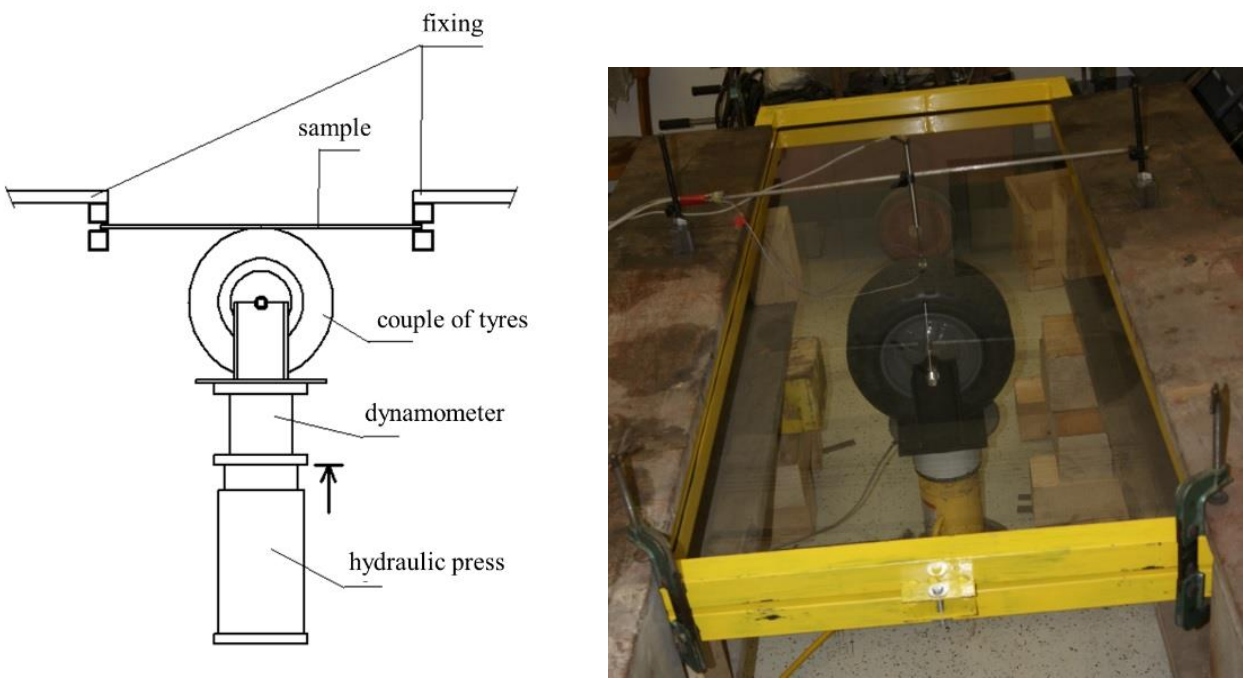

Fig. 3. Static loading test

Final destruction of glass panes is shown in figure 4 recorded using high speed camera FastecTS3. 
Table 4. Values measured in impact experiments and static load test

\begin{tabular}{|c|c|c|c|c|}
\hline Experiment & $\begin{array}{c}\text { Vertical stress } \\
{[\mathrm{MPa}]}\end{array}$ & $\begin{array}{c}\text { Horizontal stress } \\
{[\mathrm{MPa}]}\end{array}$ & $\begin{array}{c}\text { Deformation } \\
{[\mathrm{mm}]}\end{array}$ & $\begin{array}{c}\text { Force } \\
{[\mathrm{kN}]}\end{array}$ \\
\hline Static & 37.17 & 69.48 & 19.2 & 1.5 \\
\hline Impact & 77.38 & 98.28 & 34.9 & 6.6 \\
\hline
\end{tabular}
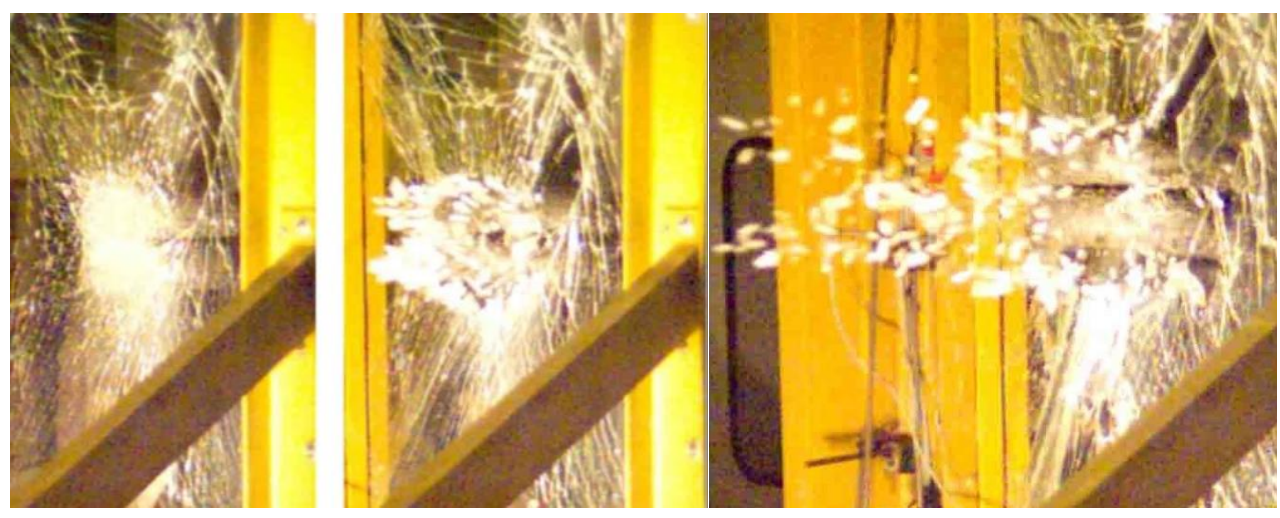

Fig. 4. Destruction of glass pane (thickness $6 \mathrm{~mm}$ fall height $1200 \mathrm{~mm}$ )

\section{Other experimental measurements}

As mentioned in chapter 1 of this paper there were conducted other experimental measurements, one of them is mentioned four point bending test according to [12].

- $\quad$ Measuring the speed of impact body

- Measurements of stiffness of rubber wheels of impact body (static approach and dynamic approach)

- Measuring the impact load of impact body

Some values obtained in these experiments are shown in Table 5.

Table 5. Results of other experimental measurements.

\begin{tabular}{|c|c|c|c|}
\hline $\begin{array}{c}\text { Fall height } \\
{[\mathrm{mm}]}\end{array}$ & $\begin{array}{c}\text { Energy released } \\
\text { by impact }[\mathrm{J}]^{*}\end{array}$ & $\begin{array}{c}\text { Measured speed } \\
{[\mathrm{m} / \mathrm{s}]}\end{array}$ & $\begin{array}{c}\text { Measured impact } \\
\text { force }[\mathrm{kN}]\end{array}$ \\
\hline 50 & 7.1 & 0.96 & 1.54 \\
\hline 100 & 13.2 & 1.36 & 2.14 \\
\hline 150 & 22.6 & 1.72 & 2.98 \\
\hline 190 & 29.3 & 1.92 & 3.46 \\
\hline 250 & 38.4 & 2.20 & 4.18 \\
\hline 450 & 74.5 & 2.96 & 6.62 \\
\hline
\end{tabular}

*Measured values on float glass pane thickness $6 \mathrm{~mm}$

\section{Conclusion}

All the presented experiments were realised in laboratory of the Department of steel and timber structures. It must be mentioned a number of prepared specimens (test samples): 20 samples for impact experiment (204 measurements); 4 samples for static load test; 4 samples for 4 point bending test. The preparation of test samples, testing and results evaluation was 
time consuming. Besides of the experimental verification there was made quiet large FEM analysis (not mentioned in this paper) published in [15].

Application of multiple measuring techniques in presented experiments is innovative and there is no mention in available science papers of such detailed experimental measuring on glass panes loaded by impact.

\section{Acknowledgement}

The authors would like to express thanks to the Grant agency of the Ministry of Education, Science, Research and Sports of the Slovak Republic for providing a grant from the research programme VEGA Nr. 1/0388/19.

\section{References}

1. L. Figuli, D. Papan, Z. Papánová, C. Bedon. Smart Structures and Systems 27(2):365378. (2021) DOI: 10.12989/sss.2021.27.2.365

2. L. Figuli, Erdelyiova, R.; Papan, D. et al. MATEC web of conferences 313 (2020)

3. L. Kruszka, R. Rekucki, Performance of protective doors and windows under impact and explosive loads. Applied Mechanics and Materials 82, pp. $422-427$ (2011)

4. L. Kruszka, R. Rekucki, Experimental Analysis of Impact and Blast Resistance for Various Built Security Components. NATO Science for Peace and Security Series C: Environmental Security, pp. 211-239 (2020)

5. D. Papan, Papanova, Z.; Figuli, L. MATEC web of conferences 313 (2020)

6. Z. Papanova, Papan, D. 2020. MATEC web of conferences 313 (2020)

7. Z. Zvaková, Production Management and Engineering Sciences - Scientific Publication of the International Conference on Engineering Science and Production Management, ESPM, pp. 577-584, (2015)

8. L. Figuli, Zvaková, Z., Bedon, C. Procedia Engineering, 192, pp. 177-182 (2017)

9. Bedon, C., Figuli, L. Transport Means - Proceedings of the International Conference 2017-September, pp. 977-984 (2017)

10. L. Balcierák. Experimental and theoretical analysis of glass planes by impact load, Dissertation thesis, 2016

11. J. Brodniansky, L. Balcierák, T. Klas, Brodniansky, Experimental pendulum tests of laminated and float glass plates. Interfaces - architecture, engineering, science - IASS (2017)

12. DIN EN 12600 Glass in building - Pendulum test - Impact test method and classification for flat glass, April 2003.

13. DIN 18008-4 Glas im Bauwesen - Bemessungs- und Konstruktionsregeln - Teil 4: Zusatzanforderungen an absturzsichernde Verglasungen

14. DIN EN 1288-3 Glass in building - Determination of the bending strength of glass Part 3: Test with specimen supported at two points (four-point bending).

15. L. Balcierák, Brodniansky, J., Klas, T. Duchoň, V., Brodniansky, J. Katona, O. Advances and Trends in Engineering Sciences and Technologies II : proceedings of the 2nd International Conference on Engineering Sciences and Technologies, Taylor \& Francis Group, pp. 39-44 (2017) 